\title{
Analysis of zinc concentration in the saliva of individuals at different age ranges
}

Open Access

Marcela Lima Cardoso Selow ${ }^{\mathrm{a}}$, Flávia Lunelli ${ }^{\mathrm{b}}$, Iran Vieira ${ }^{\mathrm{b}}$, Mariana Doff Sotta ${ }^{\mathrm{b}}$, Wilson Denis Benato Martins ${ }^{\mathrm{a}}$, Sergio Aparecido Ignacioa , João Armando Brancher $^{a}$, Marina de Oliveira Ribas ${ }^{a}$

\section{ABSTRACT}

Objectives: Zinc plays an important role in the homeostasis of the human body. In the oral cavity, its absence causes hypogeusia. Zinc supplementation acts improving taste acuity and oral lesions healing. However, some aspects regarding to salivary zinc contents and syalometric variables, as well as, its variations among age-related groups, are lacking. The objective of this study was to measure the zinc concentration in the saliva in different age range.

Methods: One hundred and twenty healthy individuals have donated saliva and they were divided in to four groups according to age: Group I = 18-29 years old; Group II = 30-39 years old; Group III: 40-49 years old and Group IV: 50-59 years old

Results: The research revealed that there are differences between salivary parameters, salivary flow rate, buffering capacity and $\mathrm{pH}$, when they are correlated with the zinc present in saliva, but the salivary zinc concentration is not age dependent.

Conclusion: $\mathrm{pH}$ and $\mathrm{BA}$ had no influence in the salivary zinc concentration, but the salivary flow can interfere in the zinc concentration.

Key words: Zinc; Saliva; Hypogeusia

\section{Análise da concentração de zinco na saliva de indivíduos de diferentes faixas de idade}

\section{RESUMO}

Objetivo: O zinco desempenha um papel importante na homeostasia do corpo humano. Na cavidade bucal, sua ausência causa hipogeusia. A suplementação com zinco melhora o paladar e promove a cura de lesões bucais. No entanto, alguns aspectos relativos ao conteúdo de zinco salivar na diferentes faixas etárias, são escassos. O objetivo deste estudo foi quantificar o zinco presente na saliva de indivíduos em diferentes faixas etárias.

Métodos: Cento e vinte indivíduos saudáveis doaram saliva e foram divididos em quarto grupos de acordo com a idade: Grupo I = 18-29 anos de idade; Grupo II = 30-39 anos de idade; Grupo III: 40-49 anos de idade e Grupo IV: 50-59 anos de idade.

Resultados: A pesquisa revelou que existem diferenças entre os parâmetros salivares analisados, fluxo salivar, capacidade tampão e pH, quando estes são correlacionados com a zinco presente na saliva, mas a concentração de zinco salivar não é varia de acordo com a idade do indivíduo.

Conclusão: pH e capacidade tampão não influenciam na concentração de zinco salivar, mas variações no fluxo salivar afetam a concentração de zinco na slaiva.

Palavras-chave: Zinco; Saliva; Hipogeusia a Pontifícia Universidade Católica do Paraná,
Curitiba, Brazil

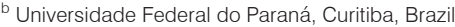




\section{INTRODUCTION}

Saliva presents various innate and acquired defense factors capable of inhibiting bacterial invasion, growth and metabolism by different mechanisms $[1,3,5]$ such as bacterial adherence and streptococci acid production [4]. So far, researches have investigated which salivary components can modulate the functions of saliva especially salivary proteins and minerals $[1,6]$.

Zinc is a stable mineral element that is involved in numerous cell metabolism reactions [7] and that is responsible for general and oral health [8]. Zinc deficiency can cause hyperkeratosis of the oral mucosa tissue [9], can increase susceptibility to dental caries when it occurs during the antenatal and postnatal periods of tooth development $[10,11]$ and is one of the major systemic causes of burning mouth syndrome [12].

Other studies have shown that zinc have antimicrobial action against oral anaerobic bacteria, especially Fusobacterium nucleatum and Prevotella intermedia inhibiting the catabolism of glutamate, glutamyl glutamate, glucose and fructose in these cells $[13,14]$. Once Fusobacterium nucleatum participates in bacterial plaque formation and zinc intervenes as a bacteriostatic agent, may be that this mineral is an important element in bacterial plaque and the reduction of gingivitis [14].

Several authors have reported that the main effect of oral zinc deficiency is a decrease in taste acuity or hypogeusia [15-18]. That taste dysfunction is a common complaint at the Tokyo Otorhinolaryngology Department [19]. According to these authors, some taste disorders are caused by chronic middle ear infections, acoustic tumors and facial paralysis, having some influence on the general health condition of the patient. Although taste disorders of unknown etiology are very common, they are always associated with decreased serum zinc concentrations $[15,18]$.

Thus, the goal of this study was to measure the zinc concentration in the saliva of individuals in different age groups and to assess possible interferences in salivary flow rate, buffer action and $\mathrm{pH}$.

\section{METHODS}

The sample was composed of 120 unrelated, both sexes, healthy individuals treated at the clinic of Dentistry of the Pontifical Catholic University of Paraná (PUCPR), CuritibaPR, Brazil. The individuals were selected for study only if the parent/caregiver returned the informed consent form, according to norms of the Ethical Committee on Research of the Center for Health and Biological Sciences of Pontifical Catholic University of Paraná (PUCPR), according to Resolution 196/96 of the Health National Council, register n. 6199 .

All examinations were conducted by one examiner. To assess the consistency of the examiner, duplicate examinations were conducted on $10 \%$ of the sample. The study sample was divided into four groups according to age: Group I $=18-29$ years old; Group II $=30-39$ years old; Group III: 40-49 years old and Group IV: 50-59 years old. If the subjects presented any oral lesion were referred for specialized care. Individuals were not included if smokers, using orthodontic appliances, taking chronic antiinflammatory and antibiotics in the last three months, or with history of any disease known to compromise immune function.

After the clinical examination, each subject was asked to collect a sample of the produced saliva according to the method established by Navazesh et al., 1992 [20]. Saliva samples were analyzed for flow rate, $\mathrm{pH}$, buffer action, and zinc concentration.

Salivary flow was evaluated by means of stimulated saliva collection. The method used was that of mechanical masticatory stimulation, using a piece of sterile rubber tourniquet of a standardized size $(1.5 \mathrm{~cm})$, masticated continuously by the patient for $6 \mathrm{~min}$. Saliva produced during the first minute of stimulation was discarded. During the following $5 \mathrm{~min}$, the patient expelled saliva into a sterilized universal collecting recipient that had been previously weighed using Marte - analytical scales, model AL 500 (São Paulo, SP, Brazil). The saliva was collected between 8 am and $10 \mathrm{am}$. Stimulated salivary flow rate (SFR) was evaluated by means of the gravimetric method and expressed in millilitre per minute [21].

Immediately following saliva collection, the salivary $\mathrm{pH}$ was assessed using a QUIMIS - Q400BD pocket $\mathrm{pH}$ meter (direct electrode) (QUIMIS, Diadema, SP, Brazil) and it was considerated normal if the value was among 6.5 and 7.5 [22]. BA was determined by titration with $3 \mathrm{ml}$ of $\mathrm{HCl} 5 \mathrm{mmol}$ added to $1 \mathrm{ml}$ of saliva. After $10 \mathrm{~min}$, the final $\mathrm{pH}$ value was measured using a pocket $\mathrm{pH}$ meter (direct electrode) and the BA was considered good if the final value was among 5-7; moderate if final value was among 4-5 and unsatisfactory if o valor was was less than 4.0 [20].

Zinc was analyzed by using inductively cople plasma optical emission spectrometry (ICP-OES) from Orion Research Inc. brand, Beverly, MA, USA.

To compare the mean values of variables among different age groups $(n=30)$, for each age group it was used Anova One-Way with level of significance of $5 \%$.

\section{RESULTS}

Table 1 shows the mean value of salivary flow rate (SFR), $\mathrm{pH}$, buffer action (BA) and zinc for saliva of male and female individuals. SFR of individuals ranged from 1.52 to $1.94 \mathrm{~mL} / \mathrm{min}$ and did not show statistical differences in the mean value according to the age ranges. Small differences were observed in the groups for salivary $\mathrm{pH}$ but nothing that can be associated with age or gender because the values are very close.

Buffer action is the ability of saliva has to maintain oral $\mathrm{pH}$ stable, inside normal limits, neutralizing acids or bases present in the oral cavity contributing to oral health. Despite group III have greater BA (5.61) all groups showed similar 
values. The latter variable analyzed was zinc and this also presented similar values between different groups: $4.04 \mathrm{mg} / \mathrm{L}$, $3.87 \mathrm{mg} / \mathrm{L}, 4.02 \mathrm{mg} / \mathrm{L}$ and $3.87 \mathrm{mg} / \mathrm{L}$, respectively. All the analyzed variables showed no significant statistical differences in the mean values according to the age ranges (Table 2).

Table 1. Mean value of biochemical parameters of saliva from studied individuals $(n=120)$. SFR $=$ salivary flow rate; $B A=$ buffer action; $\mathrm{Zn}^{2+}=$ zinc.

\begin{tabular}{|c|c|c|c|}
\hline & Groups & $N$ & Mean \\
\hline \multirow[t]{5}{*}{$\mathrm{SFR}(\mathrm{mL} / \mathrm{min})$} & 1 & 30 & 1,58 \\
\hline & $\|$ & 30 & 1,67 \\
\hline & III & 30 & 1,94 \\
\hline & IV & 30 & 1,52 \\
\hline & Total & 120 & 1,67 \\
\hline \multirow[t]{5}{*}{ Salivary pH } & I & 30 & 7,40 \\
\hline & $\|$ & 30 & 7,56 \\
\hline & III & 30 & 7,63 \\
\hline & IV & 30 & 7,56 \\
\hline & Total & 120 & 7,54 \\
\hline \multirow[t]{5}{*}{ BA } & I & 30 & 5,32 \\
\hline & $\|$ & 30 & 5,31 \\
\hline & III & 30 & 5,61 \\
\hline & IV & 30 & 5,24 \\
\hline & Total & 120 & 5,37 \\
\hline \multirow[t]{5}{*}{$\mathrm{Zn}^{2+}(\mathrm{mg} / \mathrm{L})$} & 1 & 30 & 4,04 \\
\hline & $\|$ & 30 & 3,87 \\
\hline & III & 30 & 4,02 \\
\hline & IV & 30 & 3,87 \\
\hline & Total & 120 & 3,95 \\
\hline
\end{tabular}

Table 2. p value for analysed variables.

\begin{tabular}{lcc}
\hline & $F$ & P value \\
SFR $(\mathrm{mL} / \mathrm{min})$ & 1.3679 & 0.2561 \\
Salivary $\mathrm{pH}$ & 1.4195 & 0.2407 \\
$\mathrm{BA}$ & 0.3045 & 0.8221 \\
$\mathrm{Zn}^{2+}(\mathrm{mg} / \mathrm{L})$ & 0.9060 & 0.9621 \\
\hline
\end{tabular}

Table 3. Analysis of the correlation between salivary $\mathrm{pH}$ and $\mathrm{BA}(\mathrm{rP}$ $=+0.408, p<0.05)$ and between SFR and zinc $(r P=-0.232, p<0.05)$.

\begin{tabular}{llccc}
\hline \multicolumn{3}{c}{$\begin{array}{c}\text { Correlations } \\
\text { Salivary pH }\end{array}$} & BA & $\mathrm{Zn}^{2+}(\mathrm{mg} / \mathrm{L})$ \\
SFR (mL/min) & $\begin{array}{l}\text { Pearson } \\
\text { Correlation }\end{array}$ & 0.1353 & 0.1117 & $-0.232^{*}$ \\
& $\begin{array}{l}\text { P value } \\
\text { Salivary pH }\end{array}$ & 0.1407 & 0.2244 & 0.0107 \\
& $\begin{array}{l}\text { Pearson } \\
\text { Correlation }\end{array}$ & & $0.408^{* *}$ & -0.1097 \\
& $\begin{array}{l}\text { P value } \\
\text { BA }\end{array}$ & & 0.0000 & 0.2329 \\
& Pearson & & & 0.0088 \\
& Correlation & & & 0.9237 \\
\hline & P value & & &
\end{tabular}

Since all variables showed similar values, we investigated the correlation between them. From this perspective, there is a positive correlation $(\mathrm{p}<0.05)$ between the $\mathrm{pH}$ and the $\mathrm{BA}$, however this correlation is considered regular. It was also noticed a negative correlation $(p<0.05)$ between the zinc and the salivary flow, though this correlation was weak (Table 3).

\section{DISCUSSION}

The value of saliva as a diagnostic tool for oral and systemic diseases has been studied and significant advances have been made in recent years. Saliva is produced by the salivary glands. The daily secretion of saliva varies between $800 \mathrm{~mL}$ and $1.200 \mathrm{~mL}$, and it contains mostly water (98\%), electrolytes, mucus, antibacterial compounds and several enzymes [24]. Saliva is not a serum replica, but instead it has chemical and biochemical properties of its own that are potentially applicable to clinical diagnosis. For this reason, was recommended and emphasized some of its advantages, such as immediate and noninvasive access to samples, convenient storage and transport and the stability of its components for analytical purposes [25].

In clinical practice, saliva samples are used to replace blood samples or as an additional tool for the diagnosis of certain diseases, including oral tumors, hepatitis and AIDS. Saliva is also used to monitor the concentration of drugs in the body and to verify the toxicity of metals. In this work, the saliva was used to verify, quantitatively, the zinc concentration by age ranges and whether the obtained salivary zinc values had been differences among such age ranges. Also were evaluated salivary flow rate, $\mathrm{pH}$ and buffering action.

Whole stimulated saliva was collected and the flow rate increased with increasing age although it decreased after 50 years. Although it is expected that the function of the salivary glands decreases with advancing age, similar studies have shown that the glands functions are preserved in healthy adult subjects, regardless of age [26,27].

With respect to salivary $\mathrm{pH}$, it is known that it undergoes changes after consumption of beverages and solid food and also depends on SFR and BA of saliva. It is important because it reveals the presence of acids in the mouth. Any change in $\mathrm{pH}$, down or up, may be responsible for the initiation and progression of oral diseases. There is a consensus that oral $\mathrm{pH}$, on average, ranges between 6.8 and 7.2 in different populations worldwide, with minor changes up or down, regardless of age [28]. In this study, salivary $\mathrm{pH}$ ranged between 7.4 and 7.6 and was slightly above average. Additionally, the overall BA in all individuals is normal but a regular association degree was observed between this variable and the salivary $\mathrm{pH}$, i.e., the $\mathrm{BA}$ and the salivary $\mathrm{pH}$ are directly related.

Although these variables did not show changes between groups, it was found a possible correlation among the variables SFR, BA, salivary $\mathrm{pH}$ and salivary zinc concentration (Table 3). Zinc levels can be measured 
in plasma, serum, urine or saliva although the latter is better $[29,30]$. However Watanabe et al. reported that salivary zinc levels are significantly lower than serum zinc levels [31]. According to these authors, serum zinc may sustain homeostatic concentration patterns, whereas salivary zinc is thought to be highly influenced by diet. Consequently, serum zinc measurements may have limited diagnostic value $[29,31]$.

The obtained mean values of zinc in groups I, II, III, and IV were respectively $4.04 \mathrm{mg} / \mathrm{L}, 3.87 \mathrm{mg} / \mathrm{L}, 4.02 \mathrm{mg} / \mathrm{L}$ and $3.87 \mathrm{mg} / \mathrm{L}$. Surprisingly, the salivary zinc concentration was inversely proportional to the salivary flow rate, but it is observed that there is no statistically significant difference among the zinc concentrations by age ranges.

Zinc is commonly found in association with proteins in biological fluids, including saliva. Henkin et al. (1975) hypothesized that some salivary proteins contains zinc and are related to the taste perception [30]. These salivary metalloproteins were named gustins and have unique chemical and molecular properties. Gustin represent approximately $3 \%$ of the total proteins of human parotid saliva $[30,32]$ and $75 \%$ to $80 \%$ of the zinc content of parotid saliva is exclusively associated with gustin [33]. In cases of zinc deficiency or low gustin levels in human saliva samples there will be direct damage to the taste buds and consequent hypogeusia. Appropriate doses of zinc must be prescribed to treat this condition [18].

Another important function assigned to gustin is to stabilize the oral $\mathrm{pH}$ once the primary structure of gustin is identical to the structure of carbonic anhydrase (CA), enzyme that catalyzes the reaction between hydrogen and bicarbonate regulating saliva $\mathrm{pH}[15,32,34]$. Thus, hypogeusia may be associated with the decrease of the CA activity and imbalance of oral $\mathrm{pH}$ [17].

\section{CONCLUSION}

The salivary zinc concentration is not age dependent. The buffer action and the salivary $\mathrm{pH}$ are directly associated. When the salivary flow is analyzed, it is observed that it can interfere in the zinc concentration, that is, the little the flow, the greater the zinc concentration.

\section{REFERENCES}

1. Atkison J, Baum B. Salivary enhancement: current status and future therapies. Journal of Dental Education 2001;64(10):1096-1101.

2. Amerongen VN, Veerman EC. Saliva - The defender of oral cavity. Oral Diseases 2002;8(1):12-22

3. Nariyama M, Shimizu K, Uematsu T, Maeda T. Identification of chromosomes associated with dental caries susceptibility using quantitative trait locus analysis in mice. Caries Research 2004;38:79-84.

4. Tenovuo J. Clinical applications of antimicrobial host proteins lactoperoxidase, lysozyme and lactotransferrin in xerostomia: efficacy and safety. Oral Diseases 2002;8(1):23-29

5. Singh PK, Parsek MR, Greenberg EP, Welsh MJ. A component of innate immunity prevents bacterial biofilm development. Nature 2000;417:552-5.

6. Burt BA, Pai S. Sugar consumption and caries risk: a systematic review. Journal of Dental Education 2001;65(10):1017-27.

7. King, JC, Shames, DM, Woodhouse LR. Zinc and health: curren status and future directions. American Society for Nutritional Sciences 2000;1360S-1366S; Supplement.
8. Selow MLC, Vieira I. Role of zinc in health from early childhood to old age: a brief approach. Alimentos e Nutrição (UNESP) 2007;20:20-5

9. Goto T, Komai M, Suzuki H, Furukawa Y. Long-term zinc deficiency decreases taste sensitivity in rats. J. Nutr. 2001;131(2):305-10.

10. Al-Hayali R, Hsich S, Navia JM. Gestational and post-natal dietary zinc and dental caries. J Dent Res 1981;60A:401

11. Alvares $\mathrm{O}$, Johnson D. Effects of zinc deficiency on rat parotid gland. J Oral Pathol 1981;10:430-435.

12. Siddappa K. Cutaneous and mucosal pain syndromes. Indian Journal of Dermatology. Continuing Med Edu 2002;8(3):123-30.

13. Sheng J, Nguyen PTM, Marquis RE. Multi-target antimicrobial actions of zinc against oral anaerobes. Arch Oral Biol 2005;50(8):747-57.

14. Ozdemir A, Sayal A, Alça E, Aydin A. A. The determination of salivary zinc levels following delivery from zinc containing toothpaste. J. Med. Sci 1998;28:281-3

15. Henkin RI, Martin-Brian M, Argawal-Raghunath P. Results of zinc and dysgeusia. Am. J. Med. Sci. 1999b;318(6):392-404.

16. Komai M, Goto T, Suzuki H, Takeda T, Furukawa Y. Zinc deficiency and taste dysfunction; contribution of carbonic anhydrase metalloenzyme to normal taste sensation. Biofactors 2000;12(4):65-70.

17. Sato TP, Mikami K. Recovery of a patient with a recurrent dysgeusia monitored by salivary variables and serum zinc content. Pathophysiology 2001;8:275-81.

18. Hamano $\mathrm{H}$, Yoshinaga K, Tanaka T, Eta R, Horii T, Kawabata, Furuta $\mathrm{S}$, Takei M. Polaprezinc, a zinc compound, is distributed to the lingual epithelium and increases its zinc concentration in zinc-deficient rats. Life Sci 2009;85:759-64.

19. Kobayashi T, Tomita $H$. Electron microscopic observation of vallate taste buds of zinc-deficient rats with taste disturbance. Auris Nasus - Larynx (Tokyo) Suppl. 1986;1:25-31

20. Navazesh M, Mulligan R A, Kipnis V et al. Comparison of whole saliva floe rates and mucin concentrations in healthy Caucasian young and aged adults. J Dent Res 1992;71(6):1275-8.

21. Banderas-Tarabay JA, Gonzalez-Segne M, Gardeno AS, Millan-Cortez E, Lopez-Rodrigues A, VIchis-Velazquez A. Salivary flow rate and protein concentration in human whole saliva. Salud Publica Mex 1997:5:433-41.

22. Fregonese AP, Ortega AOL, Brancher. Sialometric analysis in Young patients with chronic renal insufficiency. Spec Care Dentist 2013;1(2):1-5

23. Callegari-Jacques S. Bioestatística: Princípios e Aplicações. Artmed 2003. p. 256.

24. Resnick AZ, Shehadeh N, Shafir Y, Nagler RM. Free radical related effects and antioxidants in saliva and serum of adolescents with type 1 diabetes mellitus. Arch. Oral Biol. 2006;51:640-8.

25. Wang D, Du X, Zheng W. Alteration of saliva and serum concentrations of manganese, copper, zinc, cadmium and lead among career welders. Toxicology Letters 2008;176:40-7.

26. Baum BJ. Evaluation of stimulated parotid saliva flow rate in different age groups. J Dent Res 1981;60:1292-6.

27. Ship JA, Nolan N, Puckett S. Longitudinal analysis of parotid and submendibular salivary flow rates in healthy, different aged adults. Gerontolo Med Sci 1995;50A:M285-9.

28. Kidd EAM, Fejerskov O. What constitutes dental caries? Histopathology of carious enamel and dentin related to the action of cariogenic biofilms. $\mathrm{J}$ of Dental Research 2004;83:35-8.

29. Henkin RI. Zinc, saliva and taste: interrelationships of gustin, nerve growth factor, saliva and zinc. In: Zinc and cooper in Clinical Medicine, edited by Hambidge KM and Nichols JR. B. L. New York: SP Medical and Scientific Books 1978:35-48.

30. Henkin RI, Lippldt RE, Bilstad J, Wolf RO, Lum CKL, Edelhoch H. Zinc. J Biol. Chem. 1978;253:7556-65.

31. Watanabe M, Asatsuma M, Ikui A, Ikeda M, Yamada $Y$, Nomura S Igarashi A. Measurements of several metallic elements and matrix metalloproteinases (MMPs) in saliva from patients with taste disorders. Chemical Senses 2005;30(2):121-5.

32. Thatcher BJ, Doherty AE, Orvisky AE, Martin NM, Henkin RI. Gustin from human parotid saliva is carbonic anhydrase VI. Bioch. Bioph. Res. Com. 1998; 250(3):635-41.

33. Shatzman AR, Henkin RI. Gustin concentration changes relative to salivary zinc and taste in humans. Proc Nat Acad Sci. 1991;78(6):3867-71.

34. Henkin RI, Martin BM, Agarwal RP. Decreased parotid saliva gustin/ carbonic anhydrase VI secretion: an enzyme disorder manifested by gustatory and olfactory dysfunction. Am. J. Med. Sci. 1999;318(6):380-91. 